\title{
Reproductive Biology of Land Crabs (Gecarcoidea lalandii) in Ly Son Island, Quang Ngai Province - Vietnam
}

\author{
Huynh Minh Sang ${ }^{1^{*}}$, Le Thi Thu Thao ${ }^{1}$, Ho Son Lam ${ }^{1^{*}}$ and Phan Minh-Thu ${ }^{1,2^{*}}$ \\ ${ }^{1}$ Institute of Oceanography, Vietnam Academy of Science and Technology (VAST), Nha Trang City, \\ Vietnam. \\ ${ }^{2}$ Graduate University of Science and Technology, VAST, Ha Noi, Vietnam.
}

Authors' contributions

This work was carried out in collaboration among all authors. Authors HMS, LTTT, HSL, PMT designed the study, performed the statistical analysis, wrote the protocol and wrote the first draft of the manuscript. Authors HMS and PMT managed the analyses of the study and the literature searches. All authors read and approved the final manuscript.

Article Information

DOI: $10.9734 / A R R B / 2021 /$ v36i130336 Editor(s):

(1) Dr. Manikant Tripathi, Dr. Ram Manohar Lohia Avadh University, India. Reviewers:

(1) Luiz Gonzaga Alves dos Santos Filho UFPI, Universidade Federal do Piauí, Piauí, Brazil. (2) Duranta Diandria Kembaren, Ministry of Marine Affairs and Fisheries, Republic of Indonesia. Complete Peer review History: http://www.sdiarticle4.com/review-history/65550

Original Research Article

Received 20 December 2020

Accepted 25 February 2021

Published 17 March 2021

\begin{abstract}
The reproductive biology of the land crab Gecarcoidea lalandii was documented for the Ly Son Island, Quang Ngai Province, Vietnam. Approximately 30 crabs, collected every month in the 12month period from August 2019 to July 2020, were analyzed gonadal development stages, sex ratio, spawning season, fecundity and size at first sexual maturity. Results showed that number of male and female crab in nature was not significantly different. Gonadal of the crab passed through five stages of maturation. The crab spawns continuously during the spawning season. In nature, the crab can mature whole year-round with a higher proportion from January to August and the peak maturation from June to July. The spawning season is of this species is only on the raining period from June to July. Length at first sexual maturity of the crab was $53.91 \mathrm{~mm}$ of carapace width for female and $50.39 \mathrm{~mm}$ male crab. The absolute fecundity varied in 473,000-820,000 eggs ind ${ }^{-1}$ and highly related to body weight. The current findings provide the scientific foundation for fishery resource management and artificial breeding of the land crab in Ly Son.
\end{abstract}


Keywords: Land crabs; Gecarcoidea lalandii; reproductive biology; Ly Son Island; length at first sexual maturity.

\section{INTRODUCTION}

Land crabs (Gecarcoidea lalandii H. MilneEdwards, 1837) distribute both tropical islands and continental maritime forests and may have large populations exhibiting high densities [1]. The roles for land crabs in the ecosystems of small islands, including the transfer of energy from land to sea and vice versa, preventing or reducing colonization by exotic plant species, hastening leaf litter breakdown reducing the number of carrion-breeding flies, aerating the soil, speeding erosion, aiding soil formation and providing drinking and breeding places for other animals [2]. The land crabs genus Gecarcoidea, belonging to the family Gecarcinidae, comprise only of 2 species and is confined to the IndoPacific region. The distribution of $G$. natalis is limited to Christmas Island and Cocos Island in the Indian Ocean [3]. In contrast, G. lalandii has a wider distribution in the Indo-West Pacific islands starting from the Andaman Island eastward [4]. Numerous studies have been conducted on $G$. natalis including physiological characteristics [5]; breeding migration and behavior [6,7]. In contrast, very few studies on $G$. lalandii have been conducted in terms of reproductive biology, only one study on this crab in Taiwan [ ]. The results reveal that Ovigerous females have an average carapace width of $57 \pm 7$ (range in 42-78) $\mathrm{mm}$. The breeding season is variable, depending on the beginning of the rainy season. Ovigerous females usually release their larvae during 7-10 days in the last quarter of the lunar cycle. Larval release shows a closer relationship with the timing of sunrise than with the high tide. This species exhibits an unusual larval release behavior while clinging to vertical rock faces in which the ovigerous females drop egg masses into the water without actually entering the water. This unusual larval release from above the water and the choice of surge channels as release sites are thought to be adaptations to life on land which may reduce the risks of mortality to ovigerous females [8].

Ly Son district locates from $15^{\circ} 22^{\prime}-15^{\circ} 23^{\prime} \mathrm{N}$ and $09^{\circ} 05^{\prime}-109^{\circ} 08^{\prime} \mathrm{E}$, at the North-Eastern of Quang Ngai Province (Fig. 1). The district comprises two islands named Lon and Be Island. Nowadays, Ly Son is one of the most tourist attractive areas in Quang Ngai Province. During 2017, more than 210 thousand tourists visited Ly Son, comprise of one-third tourists visited Quang Ngai Province.
Land crab (G. lalandii) is one of the famous seafood of Ly Son. The price of this crab is around 35 to 50 USD\$/kg during the tourism season. The increasing number of tourists visiting Ly Son results in a higher demand for this land crab. As the result, there is an increase in the impacts on the natural resource of this crab in Ly Son. A survey data conducted to evaluate the natural caught of crab in Ly Son has shown that the total number caught in 2015 was around $350 \mathrm{~kg}$ and decreased to less than $270 \mathrm{~kg}$ in 2019. Thus, there is a great need for a suitable management strategy of the natural resource of the crab as well as the strategy for also breeding of this crab supporting growth, reducing the impact on natural resources. However, information available on the reproductive biology of the crab in Ly Son is still unknown.

Hence, a detailed investigation on reproductive biology including gonadal development stages, sex ratio, spawning season, fecundity and size at first sexual maturity was conducted and the results are presented and discussed in this paper.

\section{MATERIALS AND METHODS}

\subsection{Sample Collection}

The land crabs were collected from the Fishermen's Catch in Ly Son Islands (Fig. 1). from August 2019 to July 2020. The carapace width of the 348 crabs ranged from 36.04 to $92.14 \mathrm{~mm}$, average of $60.98 \pm 7.99 \mathrm{~mm}$ and the weight ranged from 15.02 to $225.60 \mathrm{~g}$, average of $74.04 \pm 32.37 \mathrm{~g}$. Around $22-36$ crabs were collected each month due to a rate species. The number of crabs collected each month is presented in Table 1.

The crabs were transported to the laboratory at the Institute of Oceanography, Vietnam for analysis. At the laboratory, the crabs were killed using the ice-slurry immersion method then weighed and measure the carapace width. The reproductive gonad of the crab (testes or ovaries) were then dissected and weighed for further analysis.

\subsection{Sample Analysis and Data Collection}

Whereas the maturity stages of females were recognized based on the macroscopic appearance of the ovary in the body cavity and 
microscopic structure of ova, in males only the macroscopic appearance of testes was considered. Gonadal development stages of crabs were determined by methods of [9] using an Olympus BX50 microscope at $10 \mathrm{X}$ and $40 \mathrm{X}$ magnification.

Histological analysis of testes and ovary was performed following the method described by [10]. Ovary or testes of each gonadal development stage of crab were dissected and fixed in $4 \%$ buffer formalin for $24 \mathrm{~h}$. After dehydrating by passing the tissue through a series of alcohol solutions of 70,85 and $98 \%$, the samples were vacuum embedded in paraffin. The histological sections $(4-5 \mu \mathrm{m})$ were stained for general morphological purposes with hematoxylin and eosin (H\&E). The samples were photographically analyzed and documented using the Olympus BX 50 microscope at $40 \mathrm{X}$ magnification.

The spawning season of the species was determined based on the availability of mature and spent individuals in the commercial landings during different months and the monthly gonadosomatic indices (GSI). The GSI was calculated $[11,12]$ using the formula:

$$
\mathrm{GSI}=100 *(\mathrm{GW} / \mathrm{BW})
$$

Where GW is the weight of gonad and BW is the weight of crab.

To estimate the length at first sexual maturity (Lm), females were grouped separately into 5 $\mathrm{mm}$ class intervals and crab in stage III and above were considered mature. Length at first sexual maturity $\left(L_{m}\right)$ was defined as the length at which 50 percent of all female crab having ovaries/testes at an advanced stage of development according to [13]. The proportion of the female crab has ovaries at the advanced stage of development $(\mathrm{P})$ of each size group was adjusted by the correction factor as the biggest size group was $100 \%$. The linear relationship between the size group and $\operatorname{Ln}(1-P / P)$ was determined and the $L_{m}$ was calculated at $P=0.5$.

The sex ratio was determined by the ratio of the number of males and females. A Chi-square test was used to test the difference between the number of males and females in the natural population of the crab. Fecundity, defined as the number of eggs per batch produced by a female, and the weight of the spawning egg (brood) mass attached to the pleopods during embryonic development were estimated. Embryonic stages were categorized by the development of color [9]: (1) initial or $1^{\text {st }}$ stage, which is yellow or orangeyellowish; (2) intermediate or $2^{\text {nd }}$ stage, which is brown; and (3) final or $3^{\text {rd }}$ stage, which is blackgrey or black. The masses at each stage were measured following the procedure described by [14] before removing each egg batch. Eggbearing pleopods were removed carefully; the wet weight of the whole egg mass (eggs + pleopods) was measured to the nearest $0.1 \mathrm{~g}$ using an electronic balance (Model: GL-602, Bogor, Indonesia). Before the removal of the eggs, the egg-bearing pleopods were immersed in $400 \mathrm{ml}$ of $1 \mathrm{M} \mathrm{KOH}$ for $12 \mathrm{~h}$. The separation process was completed by scraping the pleopods clean and removing all setae. These organs were then weighed, and their combined weight was subtracted from the whole egg mass to give the mass of the eggs alone. Three replicate subsamples of $\sim 0.2 \mathrm{~g}$ were randomly taken from each wet egg mass, and the number of eggs in each subsample was counted under a stereomicroscope mounted over a counting tray. The mean number of eggs per unit subsample weight was counted; this value was then scaled up to estimate the total number of eggs per individual egg batch.

The absolute fecundity was estimated using the formula:

Absolute Fecundity (F) $=$ (weight of ovary/weight of sample) $x$ number of oocytes in the sample.

The relationship between fecundity - weight statically determined using the following formula:

$$
\log F=a \log X+b
$$

Where $\mathrm{F}$ is demoted fecundity, $\mathrm{X}$ is the weight (gam), $a$ and b are constant.

Relative fecundity was calculated using the following formula:

$$
S=F / W
$$

Where $S$ is relative fecundity $W$ is crab weight (g).

\section{RESULTS}

Maturity stage ovary and testes of the Land crab in Ly Son Island are described in Table 2. Histology of the ovaries of the crab is present in Fig. 2. 
Ratio of male and female of Land crab in Ly Son Islands was 1:1.2 (Fig. 3). Number of male and female was not significantly different $x^{2}=2.94<$ $6.64(\mathrm{df}=1, \mathrm{p}<0.01))$.

The crab at mature (III) and ripe stages (IV) of ovaries presented all year round. However, percentages of crab at maturation stages of III, IV and $V$ were higher during the period from February to August than that during the period from September to February (Fig. 4).

Percentages of the advance stage of ovaries (IV and $\mathrm{V}$ ) in May and June were the highest $(60.88 \%$ and $61.11 \%)$ and the lowest was in October and November (33.33\%) (Fig. 4). GSI of the female crab in Ly Son Island was the highest from February $(9.26 \pm 1.07)$ to March $(9.44 \pm 2.24)$, and lowest was from September $(2.61 \pm 1.49)$ to October (2.77 \pm 1.27$)$ (Fig. 5a). For the male crab, the highest GSI was from February $(8.83 \pm 0.63)$ to March $(8.57 \pm 2.17)$, and the lowest was from October $(1.12 \pm 0.80)$ to November $(2.11 \pm 1.52)$ (Fig. 5b).

Length at first sexual maturity was $53.91 \mathrm{~mm}$ in carapace width for the female crab (Fig. 6a) and $50.39 \mathrm{~mm}$ for the male crab (Fig. 6b). The absolute fecundity of the crab in Ly Son varied in 473,000-820,000 ovaries/individual with an average of $685,152 \pm 102,707$ ovaries individual $^{-1}$. The relative fecundity varied in 4,141-7,614 with an average of $5,760 \pm 1,159$ ovaries gram $^{-1}$ of female crab. The relationship between fecundity and the carapace width of the crab was presented as in Fig. 7.

\section{DISCUSSION}

Understanding of the reproductive biology of a crustacean is very important for fishery resource management and aquaculture practices. This is the first attempt to investigate the reproductive biology parameters of the land crab (Gecarcoidea lalandii) in Viet Nam and the second study on the reproductive biology of this species in the world. The first study on the reproductive biology aspect of this species was conducted in Taiwan by [8]. This report focused on population data, breeding season, and larval release timing and behavior, with particular focus on the unusual larval release behavior in Taiwan [8]. By contrast, the present study reveals the results on gonadal development stages, sex ratio, spawning season, fecundity and size at first sexual maturity of this species in Vietnam. In this study, the gonad of the land crab Gecarcoidea lalandii was divided into 5 stages of maturity. This is normally observed in the tropical crab having the year-round reproduction cycles. At mature or ripe stages, besides the main component oocytes (oocyte at early vitellogenic and advanced vitellogenic stage), the primary growth oocytes also exist at the considerate number. This was the evidence that the crab spawns continuously during the spawning season. In Taiwan, at least some G. lalandii females can reproduce twice within a reproductive season [8]. By contrast, in the land crab Epigrapsus politus in Japan, females produced only one brood within a single breeding season [15].

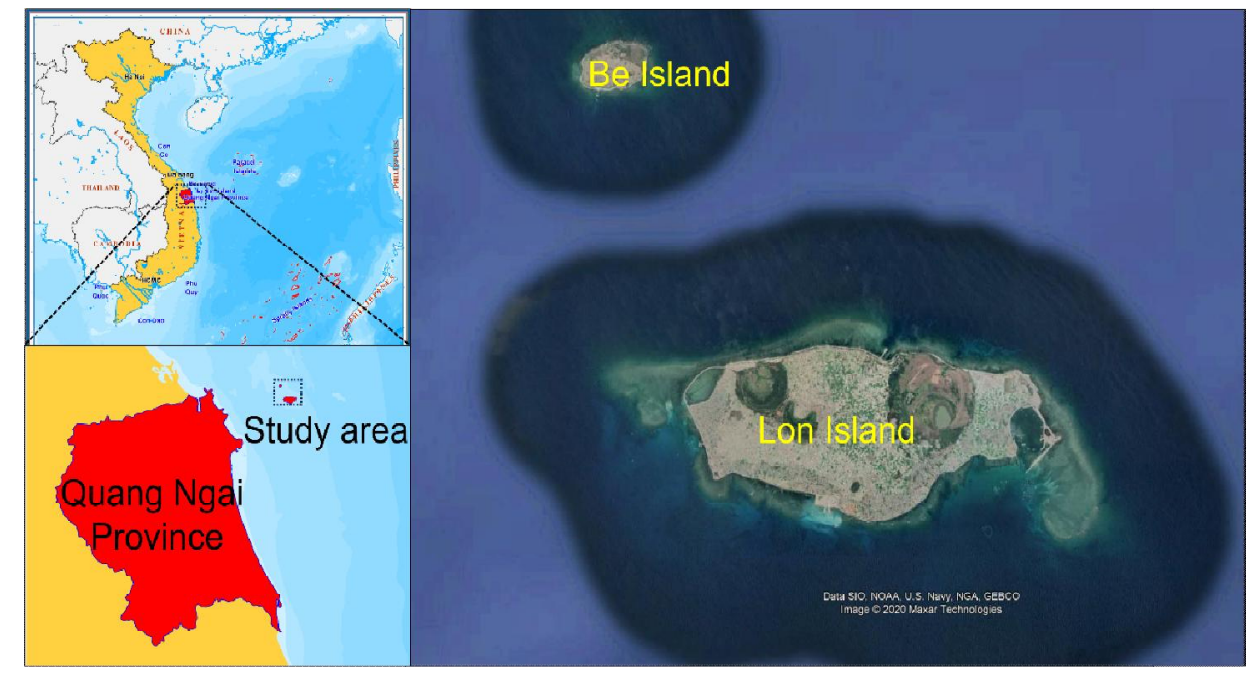

Fig. 1. Study area. The map shows the location of Ly Son district, including two Islands: Lon and be Island, beyond in the Quang Ngai Province, Vietnam 
Table 1. Number of crabs collected each month during $2019-2020$

\begin{tabular}{lllllllllllll}
\hline Month & Aug & Sep & Oct & Nov & Dec & Jan & Feb & Mar & Apr & May & Jun & Jul \\
\hline No & 22 & 32 & 30 & 30 & 30 & 31 & 23 & 30 & 30 & 31 & 23 & 36 \\
\hline
\end{tabular}
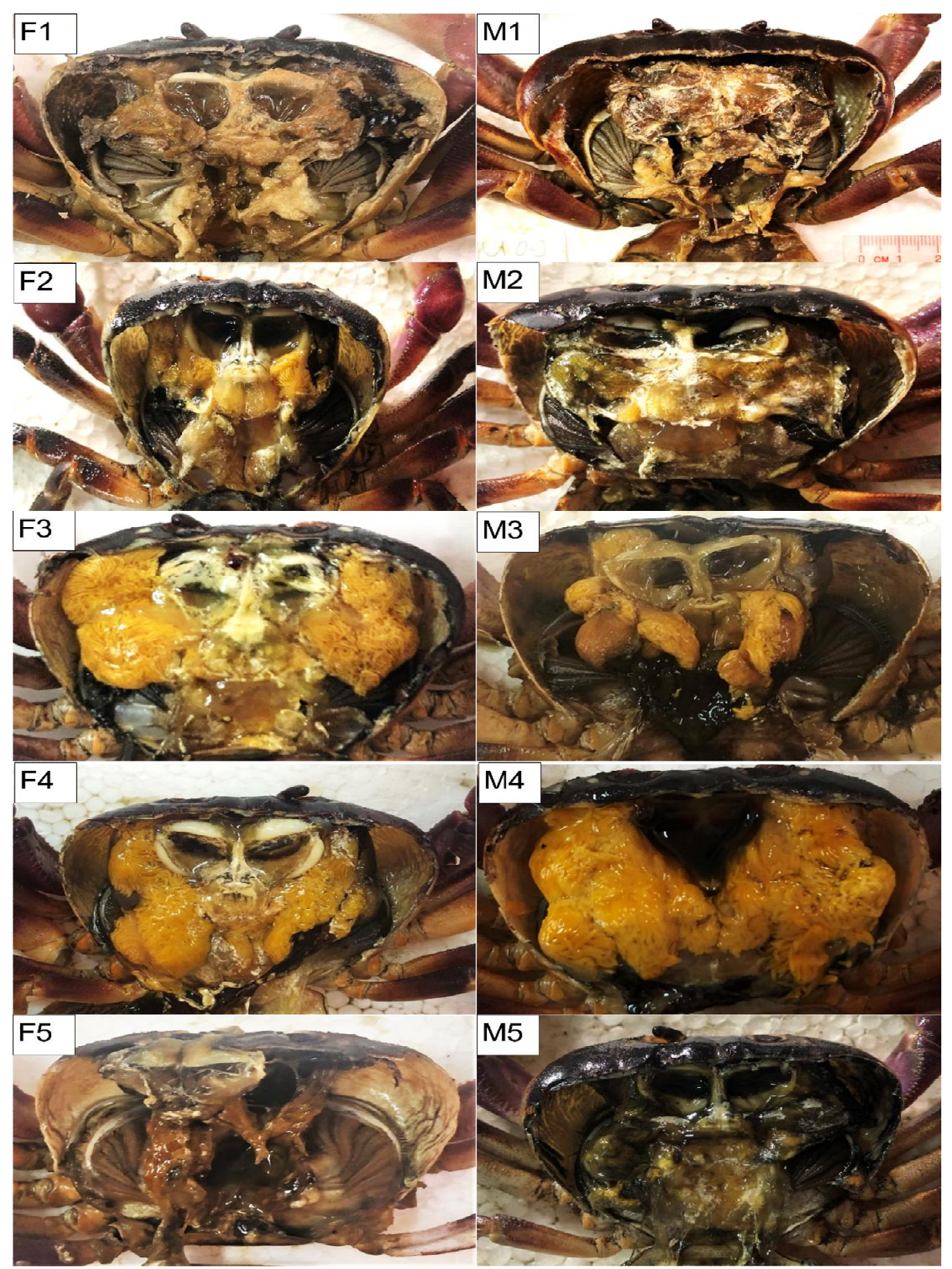

Fig. 2. Maturity stage of the ovaries and testes of the Land crab 
Table 2. Maturity stage of the ovary and testes of the Land crab in Ly Son Island

\begin{tabular}{ll}
\hline Maturity stage & Particular of ovary and testes \\
\hline $\begin{array}{l}\text { Stage I, } \\
\text { Immature }\end{array}$ & $\begin{array}{l}\text { Ovaries and testes are thin, and glassy in appearance or white. It could } \\
\text { not be distinguished ovaries and testes by snake-eyes (Fig. 2 - F1 \& M1). } \\
\text { The stage is observed in the crab size under the first maturation size }\end{array}$ \\
\hline $\begin{array}{l}\text { Stage II, } \\
\text { Maturing }\end{array}$ & $\begin{array}{l}\text { Gonad developing. Ovaries and testes are increasing in size, the Ovaries } \\
\text { and testes are cream yellow in color (Fig. 2- F2 \& M2). }\end{array}$ \\
\hline $\begin{array}{l}\text { Stage III, } \\
\text { Mature }\end{array}$ & $\begin{array}{l}\text { Ovaries and testes increase in size comparing to stage II. Ovaries and } \\
\text { testes are yellow or orange, extending about 1/2 - 1/3 of the } \\
\text { hepatopancreas area (Fig. 2- F3 \& M3). }\end{array}$ \\
\hline $\begin{array}{l}\text { Stage IV, } \\
\text { Ripe/Oozing }\end{array}$ & $\begin{array}{l}\text { Ovaries and testes increase to the maximum in size comparing to stage } \\
\text { III, extending all the hepatopancreas areas, and ready for the spawning. } \\
\text { Ovaries and testes are orange or orange - yellow in color (Fig. 2- F4 \& } \\
\text { M4). }\end{array}$ \\
\hline $\begin{array}{l}\text { Stage V, } \\
\text { spent }\end{array}$ & Ovaries and testes are rather flaccid (Fig. 2- F5 \& M5) and become rather \\
darker brown in color comparing to stage III and IV.
\end{tabular}

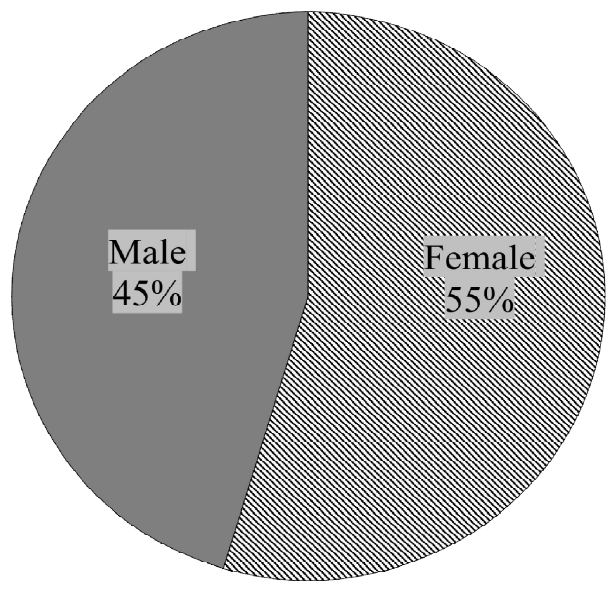

Fig. 3. Male: Female ratio of the land crab in Ly Son Islands

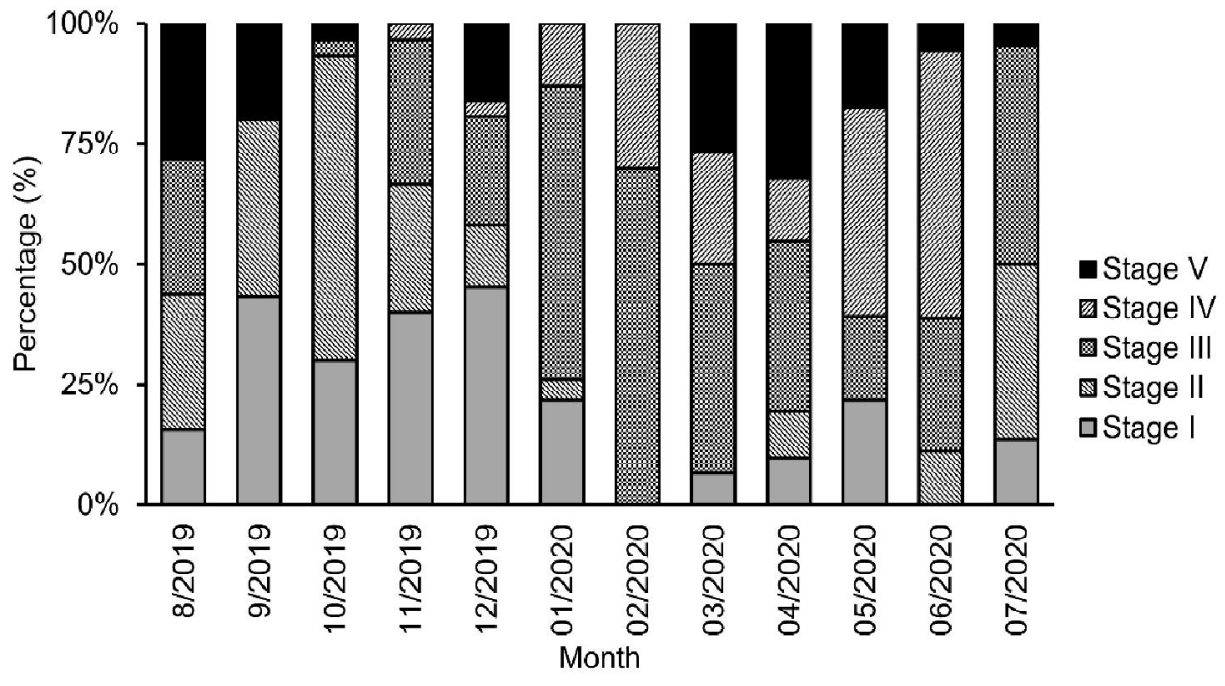

Fig. 4. Monthly percentage of different gonadal maturation stage in Land crab in Ly Son Island 

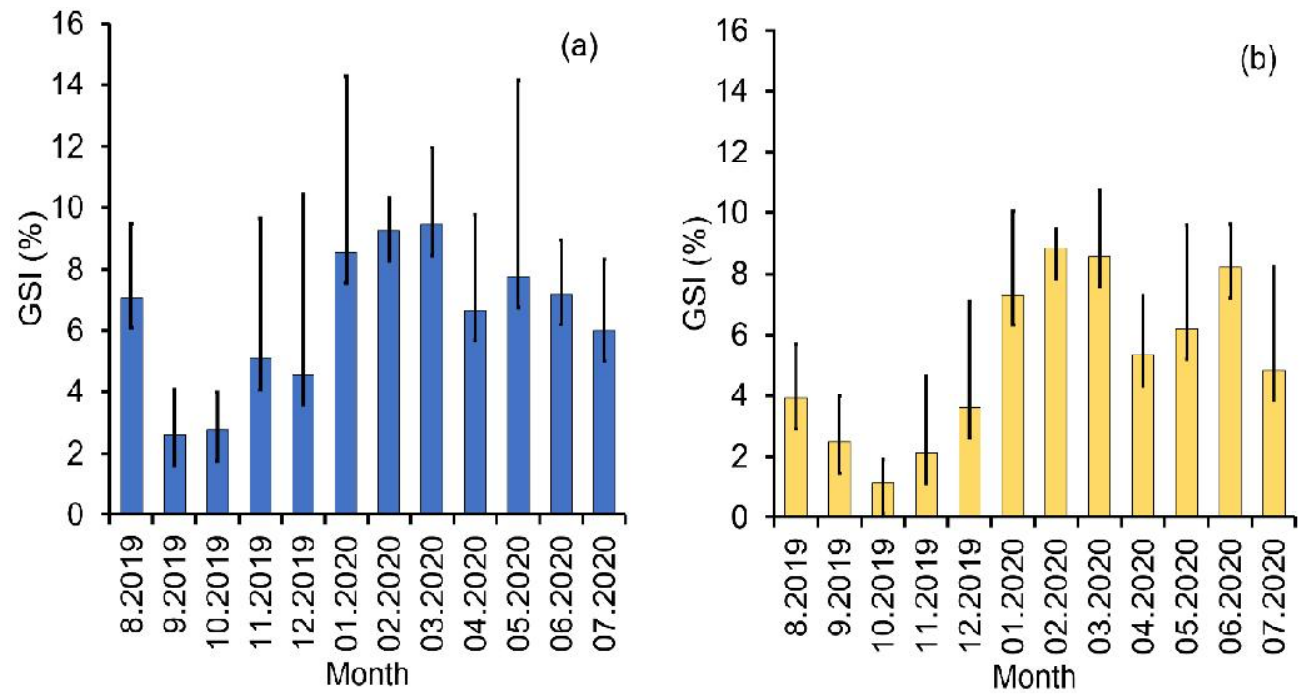

Fig. 5. GSI of female (a) and male (b) Land crab in Ly Son island
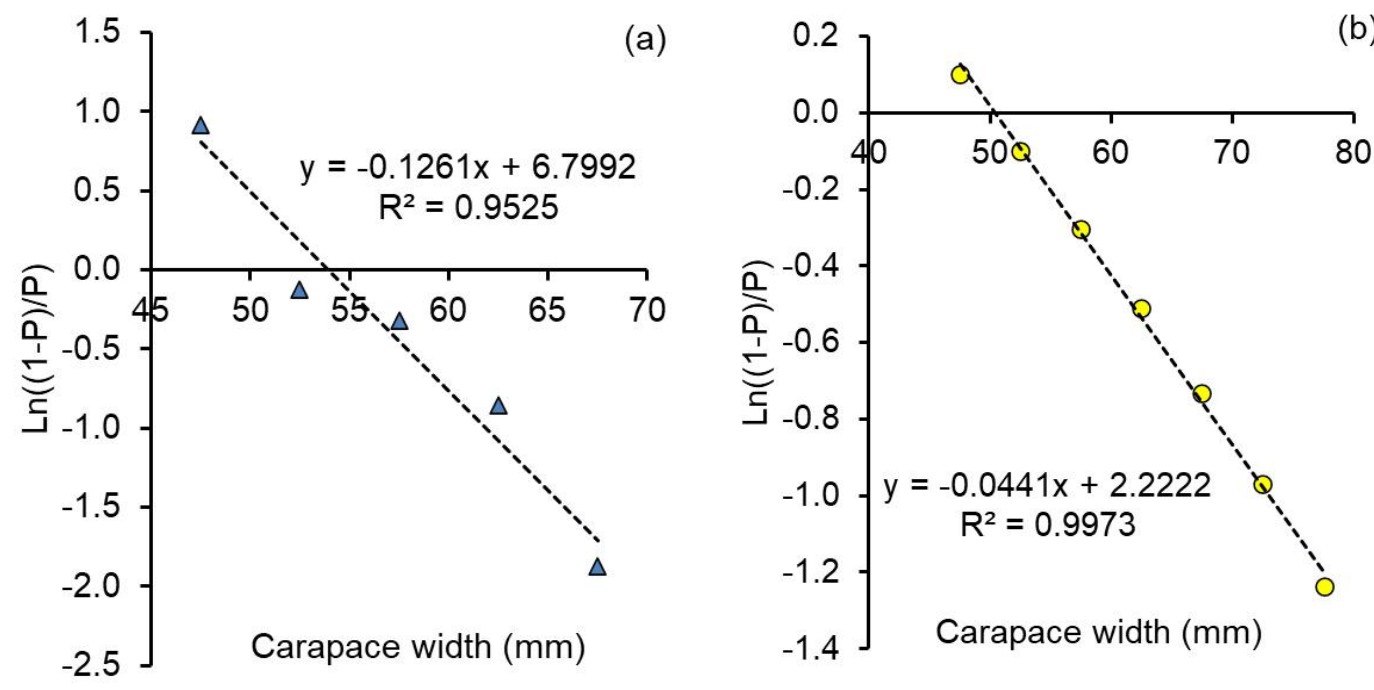

Fig. 6. Length at first sexual maturity of the female (a) and male (b) Land crab in Ly Son Island

In addition, the data on the changes in the percentage of maturity stages (stage III, IV and V) and GSI in the current study suggest that the crab can mature whole year-round with a higher proportion from January to August and the peak maturation from June to July. Even the females have gonad at stage III-IV occurs whole yearround, the ovigerous females only occur from June to July. This is the evidence that the spawning season of this species is only from June to July. This time is the rainy season in Ly Son. The results are consistent with the previous study of that $G$. lalandii in Taiwan have the reproductive cycles that begin at the onset of the rainy season, and the breeding season lasts longer and ends almost at the same time as the rainy season tapers off [8]. The breeding ecology of $E$. politus was characterized as being short and occurring in a cooler season than that of other gecarcinids inhabiting the subtropical islands of the northwest Pacific [15]. The results imply that even the gonadal of the females develop to the mature stage (III-IV), the spawning occurs only when the crab met the suitable ecological parameters such as raining, humidity. The previous studies on the land crab also reveal that the breeding season also shows different from species to species. Species of 
Cardisoma usually have a longer breeding season compared to other gecarcinids. Cardisoma guanhumi in south Florida breed from June or early July to December [16]. In Okinawa, the land crab Cardisoma hirtipes to release larvae from June to November [17]. On Aldabra, the spawning season $C$. carnifex (Herbst) on Aldabra I. lasts for 6 lunar cycles [18]. On the other hand, the breeding season of Epigrapsus notatus (Heller) only lasts for 2 months [19]. The breeding activity of $G$. natalis also lasts for 2 or 3 lunar cycles with only 1 marked by major reproductive activity. Gecarcoidea lalandii in Taiwan has a longer breeding season which lasts 4-5 months [8]. Ovigerous (egg-bearing) females Epigrapsus politus in Japan were detected from early September to late November, with the highest abundance occurring between late September and early November [15].

Fecundity of the crab is determined by the number of ova of the mature group in the ovary. In the present study, fecundity of G. lalandii, was determined from the examination of 30 specimens. Fecundity of the land crab in the present study showed a high correlation coefficient with the total weight of the crab. The regression of fecundity and total weight can be expressed as $\log F=0.451^{*} \log W+4.8928$ with $\mathrm{R}^{2}=0.8678$. This finding suggests that total ovaries in a spawning season depend on the crab size. The fecundity of the crab in Ly Son is higher than the fecundity of this crab reported for Taiwan. The number of developed larvae carried by females varies between 70,000 and 210,000 depending on the size of the female, with fecundity directly increasing with size up to $65 \mathrm{~mm} \mathrm{CW}$, then falling slightly [8].

Length at first sexual maturity of the crab was determined by the accurate method described by [13]. In the current study, female matures at a larger size (53.91 $\mathrm{mm} \mathrm{CW}$ ) than male crab (50.39 $\mathrm{mm} \mathrm{CW})$. For the male crab Johngarthia lagostoma, $60-70 \mathrm{~mm} \mathrm{CW}$ both sexes are mature. The $61-70 \mathrm{~mm} \mathrm{CW}$ class has a high proportion of ovigerous females, as do all larger classes and the smallest ovigerous female was $63 \mathrm{~mm}$ CW [20].

The results of the present study are primary basic data for natural resource management and conservation of land crab (Gecarcoidea lalandii) in Ly Son island. It is suggested that the catching of the crab is not permitted for the ovigerous females and the female crab smaller than $55 \mathrm{~mm}$ CW and male crab smaller than $51 \mathrm{~mm} \mathrm{CW}$. Besides, the catching time is inhibited from May to July. Moreover, the long-term strategy sustainable using the resource of this crab in Ly Son needs to be established.

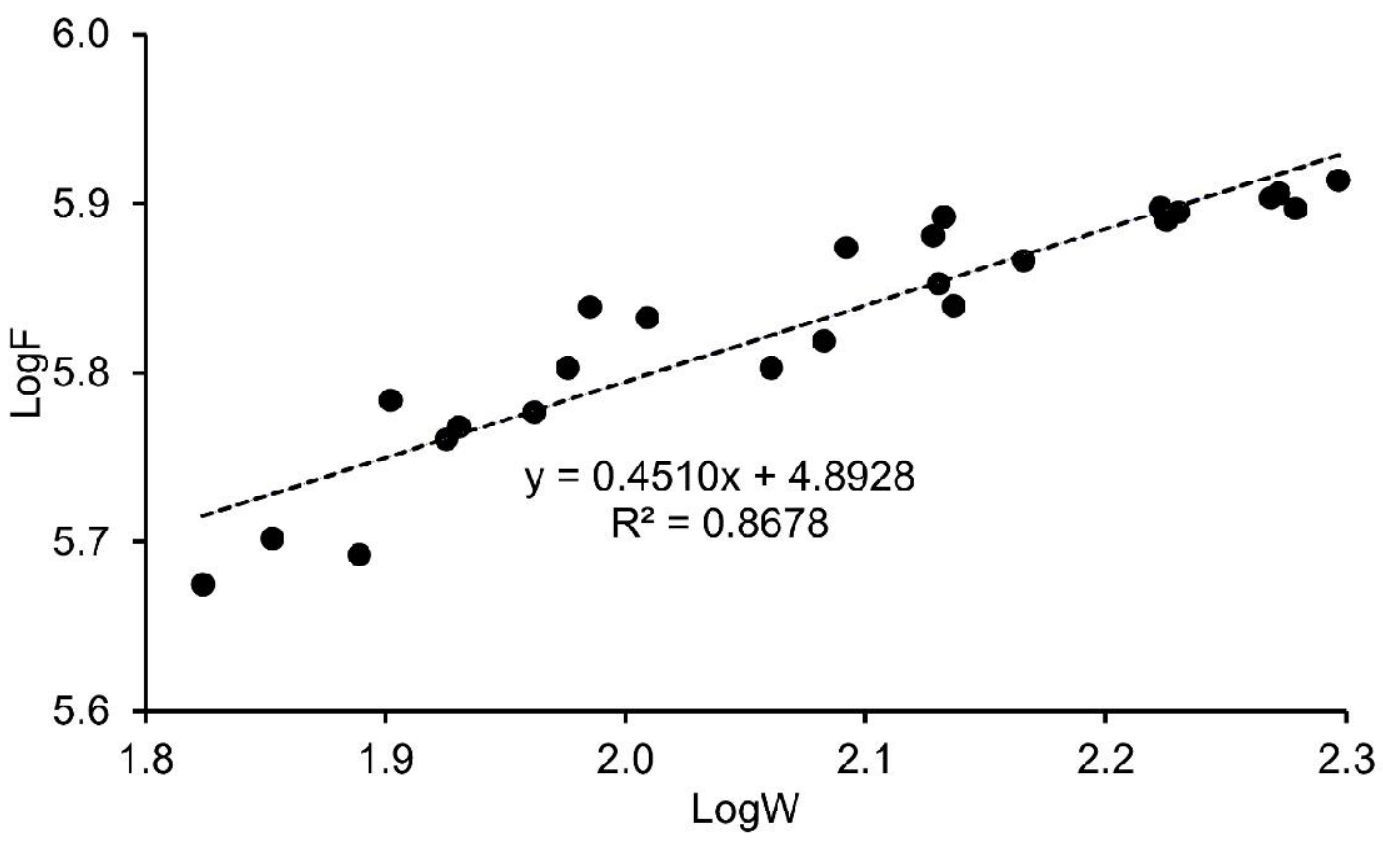

Fig. 7. Relationship between fecundity and weight of the Land crab in Ly Son island 


\section{CONCLUSION}

The land crabs are the famous food of Ly Son District. Increasing the number of tourists has put high pressured on the crab resources both in abundance and biodiversity. Our findings of reproductive biology of the land carbs is the first scientific evidences both in Ly Son Islands and in Vietnam generally. In Ly Son, the carapace width at first sexual maturity was identified in female crab of $53.91 \mathrm{~mm}$ and in male crab of $50.39 \mathrm{~mm}$, whereas the male : female ratio was $1: 1.2$. The crab can spawn continuously during the spawning season and can mature whole yearround but the peak maturation is from June to July. Therefore, to protect and conservate the land crabs in nature, it is involved the spawning season in the master strategy of biodiversity protection in Ly Son Islands.

\section{ETHICAL APPROVAL}

All authors hereby declare that "Principles of laboratory animal care" (NIH publication No. 8523, revised 1985) were followed, as well as specific national laws where applicable. All experiments have been examined and approved by the appropriate ethics committee

\section{ACKNOWLEDGMENTS}

This research was funded by the Province project of Quang Ngai, Vietnam "Survey and evaluate natural resource and propose the solution for protection, development and sustainable exploitation of the Land crab in Ly Son district, Quang Ngai Province" (project leader by Nguyen Dinh Trung). Authors wish to thank Mr. Pham Van Tuan for sample collection; MSc. Tran Cong Thinh for contributed to the sample analysis.

\section{COMPETING INTERESTS}

Authors have declared that no competing interests exist.

\section{REFERENCES}

1. Sherman PM. Effects of land crabs predation on seedling densities and distributions in a Neotropical rain forest. Journal of Tropical Ecology. 2002;18:6789.

2. Alexander HGL. A preliminary assessment of the role of the terrestrial decapod crustaceans in the Aldabran ecosystem.
Philosophical Transactions of the Royal Society B. 1979;286:241-246.

3. Hicks J, Rumpff H, Yorkston H. Christmas Crabs. 2nd Christmas Island Natural History Association; 1990.

4. Hartnoll RG. Evolution, systematics, and geographical distribution. In: McMahon BR, Burggren WW editors). biology of the land crabs. Cambridge University Press; 1988.

5. Adamczewska AM, Morris S. The functioning of the haemocyanin of the terrestrial Christmas Island red crab Gecarcoidea natalis and roles for organic modulators. Journal of Experimental Biology. 1998;201:3233-3244.

6. Adamczewska AM, Morris S. Ecology and behavior of Gecarcoidea natalis, the Christmas Island red crab, dur- ing the annual breeding migration. Biological Bulletin. 2001;200:305-320.

7. Green PT. Red crabs in rain forest on Christmas Island, Indian Ocean: Activity patterns, density and biomass. Journal of Tropical Ecology. 1997;13:17-38.

8. Liu HC, Jeng MS. Some reproductive aspects of Gecarcoidea lalandii (Brachyura: Gecarcinidae) in Taiwan. Zoological studies 2007;46:347-354.

9. Soundarapandian P. Reproductive biology of the commercially important portunid crab, Portunus sanguinolentus (Herbst). Journal of Marine Science Research and Development. 2013;3:1-9.

10. Genc MA, Yilmaz E, Genc E, Aktas M. Effects of dietary mannan oligosaccharides (MOS) on growth, body composition, and intestine and liver histology of the hybrid Tilapia (Oreochromis niloticus $\times 0$. aureus) Israel. Journal of Aquaculture. 2007;59:10 $-16$.

11. June FC. Spawning of yellow fin tuna in Hawaiian waters. Fishery Bulletin. 1953;54:47-64.

12. Yuen HSH. Maturity and Fecundity of Bigeye Tuna in the Pacific. Special Scientific Report: Fisheries No. 150. United States Department of the Interior Fish and Wildfife Service. Washington, USA; 1955.

13. King $M$, editor. Fisheries biology asenssment and mamagement, 2nd ed. Blackwell Publishing. Osney, Oxford, England; 2007.

14. Johnson DD, Gray CA, William G, Macbeth WG. Reproductive biology of Portunus pelagicus in a South-East Australian Estuary. Journal of Crustacean Biology. 2010;30:200-205. 
15. Doi W, Itoh D, Kato S, Mizutani A, Kohno $\mathrm{H}$. Reproductive biology of the land crab Epigrapsus politus Heller, 1862 (Brachyura: Gecarcinidae) on Iriomotejima, Japan. Journal of Crustacean Biology. 2020;40:200-208.

16. Gifford CA. Some observations on the general biology of the land crab, Cardisoma guanhumi (Latreille) in South Florida. Biological Bulletin. 1962;123:207223.

17. Shokita S, Shukatani N. Complete larval development of the land crab, Cardisoma hirtipes Dana (Brachyura: Gecarcinidae) reared in the laboratory. Researches on Crustasea. 1990;18:1-14.
18. Grubb P. Ecology of terrestrial decapod crustaceans on Aldabra. Philosophical Transactions of the Royal Society of London. B. 1971;260:411416.

19. Liu HC, Jeng MS. Reproduction of Epigrapsus notatus (Brachyura: Gecarcinidae) in Taiwan. Journal of Crustacean Biology. 2005;25:135-140.

20. Hartnoll RG, Broderick AC, Godley BJ, Musick S, Pearson M, Stroud SA, et al. Reproduction was studied in the land crab Johngarthia lagostoma on Ascension Island. Journal of Crustacean Biology. 2010;30:83-92.

(c) 2021 Sang et al.; This is an Open Access article distributed under the terms of the Creative Commons Attribution License ( $h$ ttp://creativecommons.org/licenses/by/4.0), which permits unrestricted use, distribution, and reproduction in any medium, provided the original work is properly cited.

Peer-review history:

The peer review history for this paper can be accessed here: http://www.sdiarticle4.com/review-history/65550 